\title{
Inhibitory Effects of a Reengineered Anthrax Toxin on Canine Oral Mucosal Melanomas
}

\author{
Adriana Tomoko Nishiya ${ }^{1}$, Marcia Kazumi Nagamine ${ }^{1}$, Ivone Izabel Mackowiak da Fonseca ${ }^{1}$,

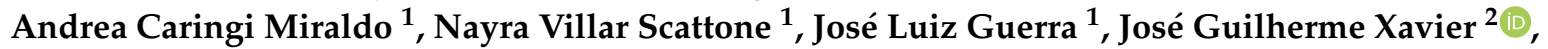 \\ Mário Santos ${ }^{2}$, Cristina Oliveira Massoco de Salles Gomes ${ }^{1}$, Jerrold Michael Ward ${ }^{3}{ }^{\mathbb{D}}$, \\ Shihui Liu ${ }^{4}$, Stephen Howard Leppla ${ }^{5}$, Thomas Henrik Bugge ${ }^{6}$ and Maria Lucia Zaidan Dagli ${ }^{1, *}$ \\ 1 Department of Pathology, School of Veterinary Medicine and Animal Science, University of Sao Paulo, \\ Sao Paulo 05508-270, SP, Brazil; adriananishiya@usp.br (A.T.N.); mknagamine@gmail.com (M.K.N.); \\ ivonemackowiak@gmail.com (I.I.M.d.F.); andreia.caringi@gmail.com (A.C.M.); \\ nayra.villar@gmail.com (N.V.S.); guerra@usp.br (J.L.G.); cmassoco@usp.br (C.O.M.d.S.G.) \\ 2 Rous Animal Pathology, Private Veterinary Pathology Services. Av. Lacerda Franco 127, Sao Paulo 01536-000, \\ SP, Brazil; xavier2126@gmail.com (J.G.X.); msantos@gmail.com (M.S.) \\ 3 Global Vet Pathology, Montgomery Village, MD 20886, USA; veterinarypathology@gmail.com \\ 4 Aging Institute and Division of Infectious Diseases, Department of Medicine, University of Pittsburg, \\ Pittsburgh, PA 15261, USA; SHL176@pitt.edu \\ 5 Microbial Pathogenesis Section, Laboratory of Parasitic Diseases, National Institute of Allergy and Infectious \\ Diseases, National Institutes of Health, Bethesda, MD 20892, USA; sleppla@niaid.nih.gov \\ 6 Proteases \& Tissue Remodeling Section, National Institute of Dental and Craniofacial Research, NIH, \\ Bethesda, MD 20892, USA; thomas.bugge@gmail.com \\ * Correspondence: mlzdagli@usp.br
}

Received: 16 January 2020; Accepted: 20 February 2020; Published: 2 March 2020

\begin{abstract}
Canine oral mucosal melanomas (OMM) are the most common oral malignancy in dogs and few treatments are available. Thus, new treatment modalities are needed for this disease. Bacillus anthracis (anthrax) toxin has been reengineered to target tumor cells that express urokinase plasminogen activator (uPA) and metalloproteinases (MMP-2), and has shown antineoplastic effects both, in vitro and in vivo. This study aimed to evaluate the effects of a reengineered anthrax toxin on canine OMM. Five dogs bearing OMM without lung metastasis were included in the clinical study. Tumor tissue was analyzed by immunohistochemistry for expression of uPA, uPA receptor, MMP-2, MT1-MMP and TIMP-2. Animals received either three or six intratumoral injections of the reengineered anthrax toxin prior to surgical tumor excision. OMM samples from the five dogs were positive for all antibodies. After intratumoral treatment, all dogs showed stable disease according to the canine Response Evaluation Criteria in Solid Tumors (cRECIST), and tumors had decreased bleeding. Histopathology has shown necrosis of tumor cells and blood vessel walls after treatment. No significant systemic side effects were noted. In conclusion, the reengineered anthrax toxin exerted inhibitory effects when administered intratumorally, and systemic administration of this toxin is a promising therapy for canine OMM.
\end{abstract}

Keywords: toxin; oral melanoma; dog; Bacillus anthracis; anthrax

Key Contribution: The reengineered anthrax toxin inhibited the growth of canine oral mucosal melanomas, causing necrosis of tumor cells and blood vessels. 


\section{Introduction}

Oral mucosal melanomas (OMM) are the most common oral malignancy in dogs [1,2]. OMM are characterized by local infiltration and metastasis to regional lymph nodes (11.4-53\% of cases) [3,4] and lungs (23-27\%). Recurrence rates are between 3.2 and $10 \%$ and the median survival after diagnosis ranges from 65 to 1020 days [4-7]. The common treatment modalities for OMM include surgery, radiation therapy, chemotherapy and immunotherapy [2]. Novel strategies, like vaccines, are commercially available and have some inhibitory effects [8,9]. Some new therapies, such as nanotechnology-based immunotherapy [10], electro-chemotherapy [11], and toceranib phosphate (Palladia $\left.{ }^{\circledR}\right)$, alone or in combination [12], have also been reported, but only partial responses were observed. Thus, new treatments for OMM are needed.

Here we report the results of a clinical study on the effects of a reengineered anthrax toxin on canine OMM. The anthrax (Bacillus anthracis) toxin is composed of three individual proteins - lethal factor (LF), edema factor (EF), and protective antigen (PA). None of the three subunits displays any biological effects in animals when administered alone, but PA combined with EF or LF cause skin edema and death, respectively, in animals $[13,14]$.

Since 1999, the group of Liu, Leppla and Bugge from the National Institutes of Health (NIH) has been working on the potential of the anthrax toxin to treat cancer $[13,15]$. Their goal was to modify the anthrax toxin components so that it could use resources from the tumor cells to selectively kill them.

To kill host cells, the PA native anthrax toxin subunit binds to endothelial cell surface receptors called Tumor Endothelial Marker 8 (TEM8 or ANTXR1) or Capillary Morphogenesis Gene 2 (CMG2 or ANTXR2) [16], and is subsequently cleaved by a furin protease on the cell membrane surface [17]. This cleavage generates a 63-kDa C-terminal fragment that subsequently forms a PA heptamer that binds and translocates up to three molecules of LF or EF into the cytosol. EF is a potent adenylate cyclase protein that kills cells by raising cyclic adenosine monophosphate (cAMP) levels, whereas LF is a metalloproteinase that cleaves and inactivates mitogen-activated protein kinase kinases (MEKs), thereby blocking the extracellular signal-regulated kinase (ERK)/mitogen-activated protein kinase (MAPK) pathway [18].

To selectively kill tumor cells, the reengineered anthrax toxin targets three over-expressed proteins: The urokinase-type plasminogen activator (uPA) and its receptor (uPAR), and the metalloproteinases (MMPs). Thus, mutated anthrax toxin-protective antigen (PA) proteins, in which the furin cleavage site is replaced by sequences cleaved specifically by uPA, and modified PA proteins, in which the furin protease cleavage site is replaced by sequences selectively cleaved by MMPs, were developed. The high cytotoxicity of anthrax toxin and the overexpression of uPA/uPAR and MMP in various tumor types favored the construction of mutated versions of PA [18]. To further enhance tumor specificity, inter-complementing Bacillus anthracis toxin was engineered to be dependent on the activation of uPAs and MMP. The inter-complementing toxin consists of PA variants PA-U2-R200A and PA-L1-I210A, which cause cell death by disruption of the MAPK signaling pathway when associated with LF. In vivo, this association showed the best therapeutic index for xenografted human melanomas and carcinomas $[19,20]$. Nevertheless, the efficacy of the engineered anthrax toxin has never been tested on canine tumors.

Proteinases urokinase (uPA) and metalloproteinases (MMPs) are overexpressed in a variety of tumor cells and are rarely present in physiologically normal cells [21]. Canine melanocytic tumors showed high MMP-2 activity [22] and melanoma cell lines express MMP-9 [23]. To date, uPA and uPAR have not been studied in canine OMM, but expression occurs throughout the canine genitourinary tract [24] and in canine mammary tumors [25]. Dogs are considered good models for human cancers, and here, we test the effects of a re-engineered anthrax toxin on canine OMM. 


\section{Results}

\subsection{Clinical and Histological Characteristics}

Five dogs (numbered 1 to 5) with spontaneous OMM were included in the study and the dogs' and OMM characteristics can be seen in Table 1. Four animals were male and age and weight ranged from 11 to 16 years and 5, to 33,3 Kg, respectively. OMM staging ranged from I/IV (dog 5) to III/IV (dogs 1-4) and tumors were mostly located in the maxilla (3/5), followed by mandible (1/5), and hard palate (1/5). Animals 1-4 presented lymph node metastasis. Initial tumor volume ranged from 228 to $18602 \mathrm{~mm}^{3}$ before treatment.

Table 1. Canine oral mucosal melanomas (OMM) characteristics and staging in five dogs of the study.

\begin{tabular}{|c|c|c|c|c|c|c|}
\hline Dog & $\begin{array}{c}\text { Breed; Gender; } \\
\text { Age; Weight (Kg) }\end{array}$ & $\begin{array}{l}\text { Staging A } \\
\text { (I-IV) }\end{array}$ & $\begin{array}{c}\text { Histological } \\
\text { Type }^{B}\end{array}$ & $\begin{array}{l}\text { Initial Volume }{ }^{\mathrm{C}} \\
\qquad\left(\mathrm{mm}^{3}\right)\end{array}$ & $\begin{array}{l}\text { Main Diameter } \\
(\mathrm{mm})\end{array}$ & Localization \\
\hline 1 & $\begin{array}{c}\text { Yorkshire; Male; } \\
11 ; 5,4\end{array}$ & $\begin{array}{c}\text { III } \\
(\mathrm{T} 2 \mathrm{~N} 1 \mathrm{bM} 0)\end{array}$ & $\begin{array}{l}\text { Amelanotic, } \\
\text { epithelioid }\end{array}$ & 18602 & 50,6 & $\begin{array}{c}\text { Left } \\
\text { mandible }\end{array}$ \\
\hline 2 & $\begin{array}{c}\text { Daschund; Male; } \\
14 ; 7,3\end{array}$ & $\begin{array}{c}\text { III } \\
(\mathrm{T} 2 \mathrm{~N} 1 \mathrm{bM} 0)\end{array}$ & $\begin{array}{l}\text { Melanotic, } \\
\text { spindle }\end{array}$ & 2509 & 36,5 & Left maxilla \\
\hline 3 & $\begin{array}{c}\text { Mongrel; Female; } \\
16 ; 5,7\end{array}$ & $\begin{array}{c}\text { III } \\
(\mathrm{T} 2 \mathrm{~N} 1 \mathrm{bM} 0)\end{array}$ & $\begin{array}{c}\text { Melanotic } \\
\text { balloon cells }\end{array}$ & 8875 & 35,4 & $\begin{array}{l}\text { Right } \\
\text { maxilla }\end{array}$ \\
\hline 4 & $\begin{array}{c}\text { Labrador; Male; } \\
14 ; 33,3\end{array}$ & $\begin{array}{c}\text { III } \\
(\mathrm{T} 2 \mathrm{~N} 1 \mathrm{bM} 0)\end{array}$ & $\begin{array}{l}\text { Melanotic, } \\
\text { desmoplastic }\end{array}$ & 7613 & 37,5 & Pre maxilla \\
\hline 5 & $\begin{array}{c}\text { Lhasa Apso; Male; } \\
12 ; 5,0\end{array}$ & $\begin{array}{c}\text { I } \\
\text { (T1aN0M0) }\end{array}$ & $\begin{array}{l}\text { Melanotic, } \\
\text { spindle }\end{array}$ & 228,3 & 7,7 & Hard palate \\
\hline
\end{tabular}

\subsection{Evaluation of the Clinical Response of Canine OMM to the Reengineered Anthrax Toxin}

The five dogs were treated with intratumoral doses of the reengineered anthrax toxin and LF for assessing the efficacy of in vivo treatment. Dogs 1 and 2 received 6 injections of the toxin in 14 days of treatment whereas dogs 3, 4, and 5 received 3 inoculations of the toxin every other day, within 7 days. Variation in treatments between dogs was based on clinical findings in the first dogs injected. Dogs 1 and 2 were treated with 6 intratumoral applications of the anthrax toxin (during 14 days), while dogs 3 , 4 and 5 were treated with only 2 doses, during 7 days. Dogs 1 and 2 were treated first, and at the 9 th day after treatment an increase in tumor volumes was observed, probably due to the production of antibodies against the toxin, as mentioned by Liu et al., 2016 [27]. This effect could impair the response to treatment, causing the increase in volume and discomfort to the animal. Therefore, dogs 3,4 , and 5 received only 3 intratumoral injections of the toxin.

The clinical response to the reengineered toxin treatment was evaluated during the first seven or 14 days before surgery. There was no disease progression; 4 dogs showed tumor reduction varying from 12 to $63 \%$ (Table 2, Figure 1). One dog (dog 3) showed 20\% increase in the tumor, due to local edema.

Table 2. Volume reduction of OMM after reengineered anthrax toxin treatment in dogs.

\begin{tabular}{|c|c|c|c|}
\hline Dog/Breed & $\begin{array}{l}\text { Tumor Volume } \\
\text { Day } 0\left(\mathrm{~mm}^{3}\right)^{A}\end{array}$ & $\begin{array}{c}\text { Tumor Volume Day } 7 \text { or } \\
\qquad 14\left(\mathrm{~mm}^{3}\right)^{A}\end{array}$ & $\%$ of Tumor Reduction \\
\hline 1 Yorkshire terrier & 18602 & 16402 (day 14) & $12 \%$ \\
\hline 2 Daschund & 2509 & 1341 (day 14) & $47 \%$ \\
\hline 3 Mongrel & 8895 & 10754 (day 7) & $20 \%(+)$ \\
\hline 4 Labrador retriever & 7613 & 2847 (day 7) & $63 \%$ \\
\hline 5 Lhasa apso & 228,3 & 148 (day 7) & $34 \%$ \\
\hline
\end{tabular}

${ }^{A}$ Volume $=$ length $\times$ width $^{2} / 2$ (Sugiura et al., 1952) [28]. 


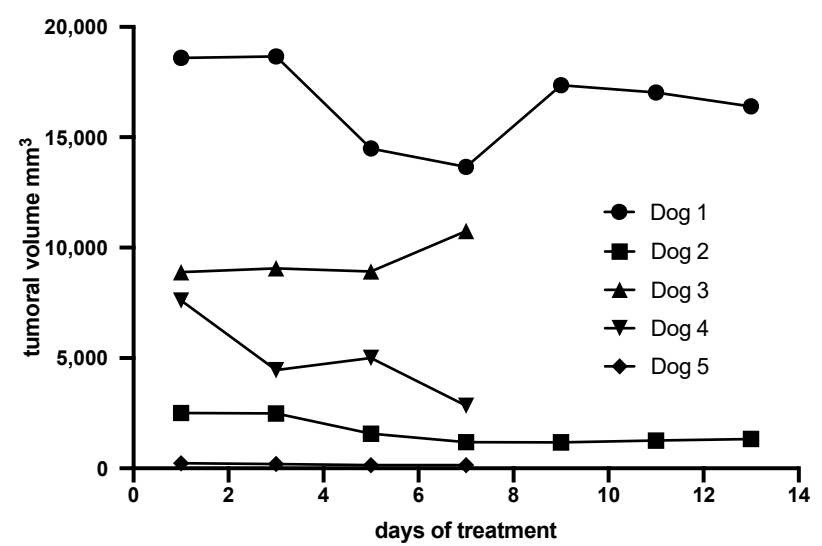

Figure 1. Tumoral volume of canine OMM in 5 dogs after intratumoral treatment with the reengineered anthrax toxin.

Clinical examination revealed enlarged sentinel lymph nodes after the first injection of the toxin and decreased tumor bleeding after 3 or 6 injections in all dogs. The toxin was generally well tolerated; local facial edema and ulceration of oral mucosa were observed only in $\operatorname{dog} 2$. The treatment with the reengineered anthrax toxin caused no adverse effects like weight loss or significant changes in blood parameters, including packet cell volume (Ht), total leukocytes (Leuko), serum alanine aminotransferase (ALT), alkaline phosphatase (ALP), urea (Urea), creatinine (Creat), and platelets (Plat) (Table 3). No significant systemic side effects were noted in any animals; dogs 2 and 5 were still alive 532, and 288 days, respectively, after the intratumoral toxin treatment followed by surgery.

Table 3. Clinical pathology data of five dogs included in the study, before and after (b/a) the intratumoral inoculations of the reengineered anthrax toxin.

\begin{tabular}{|c|c|c|c|c|c|c|c|c|}
\hline Dog & $\begin{array}{c}\text { PCV } \\
(\%) \\
(b / a)\end{array}$ & $\begin{array}{c}\text { Leukocytes } \\
(\times 1000 \text { cels } / \mu L) \\
(b / a)\end{array}$ & $\begin{array}{c}\text { Alanine } \\
\text { transferase } \\
\text { (U/L) } \\
(\mathrm{b} / \mathrm{a})\end{array}$ & $\begin{array}{c}\text { Alkaline } \\
\text { Phosphatase } \\
\text { (U/L) } \\
\text { (b/a) }\end{array}$ & $\begin{array}{c}\text { Urea } \\
\text { (mg/dl) } \\
\text { (b/a) }\end{array}$ & $\begin{array}{c}\text { Creatinin } \\
(\mathrm{mg} / \mathrm{dl}) \\
(\mathrm{b} / \mathrm{a})\end{array}$ & $\begin{array}{c}\text { Platelet } \\
(\times 1000 / \mathrm{mL}) \\
(\mathrm{b} / \mathrm{a})\end{array}$ & $\begin{array}{l}\text { Weeks after } \\
\text { Treatments }\end{array}$ \\
\hline 1 & $46 / 40$ & $19,9 / 28,4$ & $43 / 12$ & $29 / 69$ & $43 / 47$ & $1,0 / 0,8$ & $366 / 285$ & 5 \\
\hline 2 & $50 / 43$ & $34 / 12,9$ & $31 / 56$ & $248 / 655$ & $58 / 34$ & $0,7 / 0,9$ & $569 / 407$ & 9 \\
\hline 3 & $34 / 25$ & $29,6 / 14,1$ & $99 / 264$ & $395 / 691$ & $64 / 94$ & $1,3 / 1,3$ & $678 / 474$ & 14 \\
\hline
\end{tabular}

2.3. Histopathology, Immunostaining, and Cell Proliferation of Canine OMM Before and After Treatment with the Reengineered Anthrax Toxin

Histopathological diagnosis of OMM are presented in Tables 1 and 4. Dog 1 had an amelanotic melanoma, while dogs 2, 3, 4, and 5 had melanotic OMM. 
Table 4. Clinical response of OMM after toxin treatment in five dogs.

\begin{tabular}{|c|c|c|c|c|c|}
\hline Dog & $\begin{array}{c}\text { Breed; Gender; } \\
\text { Age; Weight (Kg) }\end{array}$ & $\begin{array}{l}\text { Histological } \\
\text { Type }^{A}\end{array}$ & $\begin{array}{c}\text { Main } \\
\text { Diameter (mm) } \\
\text { before Toxin } \\
\text { Inoculation }\end{array}$ & $\begin{array}{c}\text { Main } \\
\text { Diameter }(\mathrm{mm}) \\
\text { after Toxin } \\
\text { Inoculation }^{\mathrm{B}}\end{array}$ & cRECIST $^{B}$ \\
\hline 1 & $\begin{array}{l}\text { Yorkshire terrier; } \\
\text { Male; } 11 ; 5,4\end{array}$ & $\begin{array}{l}\text { Amelanotic, } \\
\text { epithelioid }\end{array}$ & 50,6 & 45 & Stable disease \\
\hline 2 & $\begin{array}{l}\text { Daschund; Male; } \\
14,7,3\end{array}$ & $\begin{array}{l}\text { Melanotic, } \\
\text { spindle }\end{array}$ & 36,5 & 32,1 & Stable disease \\
\hline 3 & $\begin{array}{l}\text { Mongrel; Female; } \\
16 ; 5,7\end{array}$ & $\begin{array}{c}\text { Melanotic } \\
\text { balloon cells }\end{array}$ & 35,4 & 35,1 & Stable disease \\
\hline 4 & $\begin{array}{l}\text { Labrador; Male; } 14 ; \\
33,3\end{array}$ & $\begin{array}{c}\text { Melanotic, } \\
\text { desmoplasic }\end{array}$ & 37,5 & 32,3 & Stable disease \\
\hline 5 & $\begin{array}{l}\text { Lhasa Apso; Male; } \\
12 ; 5,0\end{array}$ & $\begin{array}{l}\text { Melanotic, } \\
\text { spindle }\end{array}$ & 7,7 & 6,7 & Stable disease \\
\hline
\end{tabular}

The histological changes observed after treatment with the reengineered anthrax toxin were mainly inflammation infiltrating the tumor masses, with predominance of lymphocytes in melanomas of dogs 1 to 4 and of neutrophils in dog 5 . Areas of necrosis, hemorrhage, and edema were identified in histological sections from dogs 1 to 4 (Table 5, Figure 2). Only dog 5 had no lymph node metastasis. Histopathology of tumors from animals 3, 4, and 5 showed necrosis in blood vessel walls after intratumoral treatment with the reengineered anthrax toxin (Figure 3).

Table 5. Presence or absence of necrosis in histopathological analysis and quantification of Ki-67 positive cells in OMM after intratumoral treatment with reengineered anthrax toxin.

\begin{tabular}{cccc}
\hline Dog & $\begin{array}{c}\text { Necrosis/ } \\
\text { Endothelial Cells Necrosis } \\
\text { after Treatment }\end{array}$ & $\begin{array}{c}\text { Ki67 Positive Cells } \\
\text { Quantification (\%) } \\
\text { before Treatment }\end{array}$ & $\begin{array}{c}\text { Ki67 Positive Cells } \\
\text { Quantification (\%) after } \\
\text { Treatment }\end{array}$ \\
\hline 1 & Yes/no & $\geq 19$ & $\geq 19$ \\
2 & Yes/no & $\geq 19$ & 12,2 \\
3 & Yes/yes & $\geq 19$ & 7 \\
4 & Yes/yes & 8,2 & 4,6 \\
5 & Yes/yes & 3,6 & 16 \\
\hline
\end{tabular}



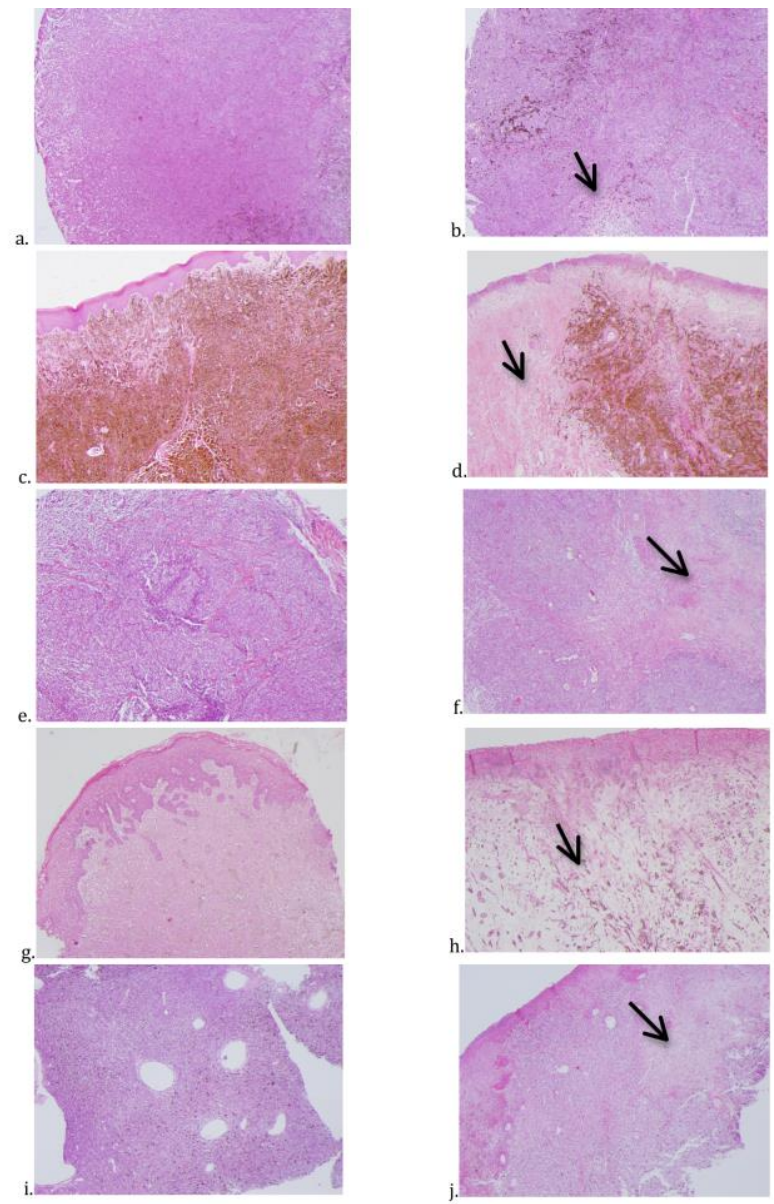

Figure 2. Photomicrographs of canine OMM biopsy samples from dogs $1(\mathbf{a}, \mathbf{b}), 2(\mathbf{c}, \mathbf{d}), 3(\mathbf{e}, \mathbf{f}), 4$ (g,h) and $5(\mathbf{i}, \mathbf{j})$, obtained before $(\mathbf{a}, \mathbf{c}, \mathbf{e}, \mathbf{g}, \mathbf{i})$ and after $(\mathbf{b}, \mathbf{d}, \mathbf{f}, \mathbf{h}, \mathbf{j})$ the intratumoral treatment with the reengineered anthrax toxin. In samples obtained after the treatment, it is possible to see necrotic areas (arrows), as well as edema and hemorrhage. All photomicrographs were obtained in a stereo microscope (Nikon ${ }^{\circledR}$ ), with a magnification of $5 \times$. (H\&E, Scale bar $=0.5 \mathrm{~mm}$.).

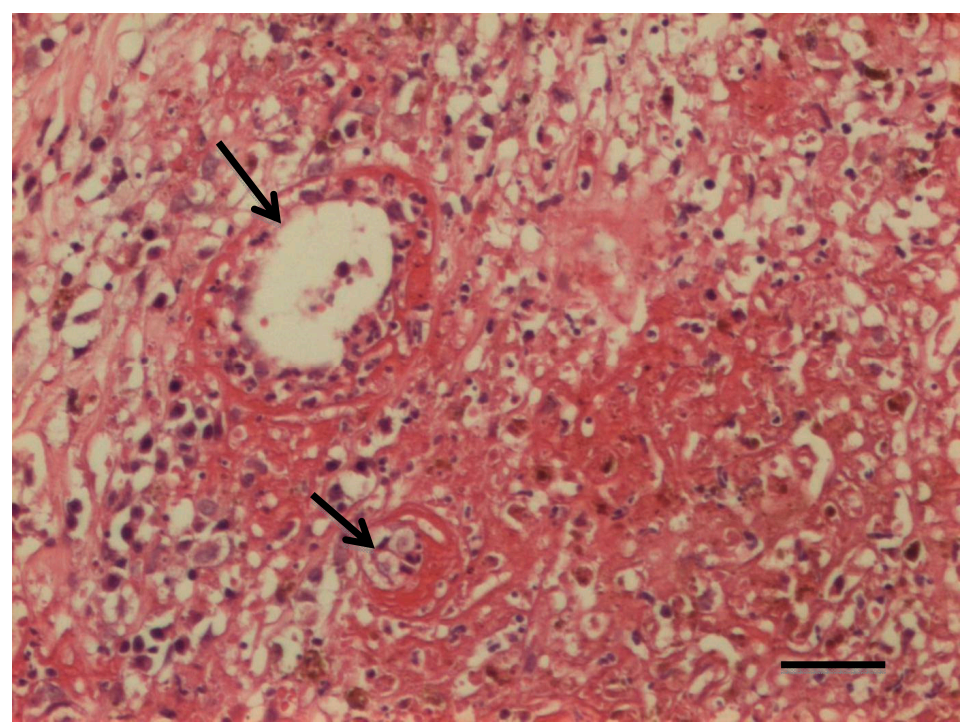

Figure 3. Detail of histopathological sample of OMM from dog 4, showing necrosis of the blood vessel walls (arrows). (H\&E, Scale bar $=100 \mu \mathrm{m}$.). 
Cell proliferation of the toxin treated tumors was determined by immunostaining with the cell proliferation marker Ki-67. Three animals (dogs 2, 3, and 4), had a decreased Ki-67 index after toxin treatment (Table 5).

Immunostaining for uPA, uPAR, MMP-2, MT1-MMP, and TIMP-2 was positive for most dogs, except MT1-MMP for dog 1 (Table 6).

Table 6. Immunostainings of uPA, uPAr, MMP-2, MT1-MMP and TIMP-2 in dogs 1-5 with OMM.

\begin{tabular}{cccccc}
\hline Dog & uPA & uPAr & MMP-2 & MT1-MMP & TIMP-2 \\
\hline 1 & + & + & + & + & + \\
2 & + & + & + & + & + \\
3 & + & + & + & + & + \\
4 & + & + & + & + & + \\
5 & + & + & + \\
\hline
\end{tabular}

\section{Discussion}

The treatment of both human and animal cancers still remains one of the greatest challenges to science. Among domestic animals, and similarly to humans, dogs are living longer and are the most affected by several types of neoplasia.

Murine cancer models have been useful for analyzing the biology of pathways involved in cancer initiation, promotion, and progression. However, they often lack features that define cancer in humans, including long periods of latency, genomic instability, tumor cell heterogeneity, and its surrounding microenvironment. More importantly, the complex biology of cancer recurrence and the development of metastases are not adequately reproduced in the conventional models of laboratory animals used in the development of antineoplastic drugs. Due to these shortcomings, the development and approval of new cancer drugs has been a lengthy and expensive process, and therefore, additional models that better represent human disease are needed.

In this scenario, veterinary oncology has recently gained significant prominence in the scientific community, particularly canine comparative oncology. Tumors of dogs and humans have several similarities, including histological appearance, genetic alterations, molecular targets, biological behavior, and responses to conventional therapies [30]. In fact, several research groups around the world have turned their attention to spontaneous cancers of dogs as models of human neoplasms, since the dog genome published in 2005 [31] showed many similarities between the two species.

Several types of neoplasms, including, among others, melanomas, share indisputable similarities with the corresponding ones in humans. [32,33]

Canine OMM is an aggressive disease, and this study aimed to evaluate a new possible targeted therapy for these tumors. Evidence for the antineoplastic action of the re-engineered anthrax toxin in experimental studies has prompted us to begin testing on canine OMM.

Bacillus anthracis toxin has been studied since 1955 on the evidence of high lethality in mice and guinea pigs. The toxin consists of three subunits: A protective antigen (PA), an edema factor (EF) and lethal factor (LF). PA is cleaved by furin proteases on the cell membrane forming an active heptamer (PA63) bound to the Bacillus anthracis toxin receptor (TEM8 or CMG2). This association forms a channel through which EF and LF can translocate into the cytosol, causing cell death $[13,17,27,34-36]$ by increasing levels of intracellular cAMP, or blocking proteins of the MAPK signaling pathway, respectively $[5,37,38]$.

Evidence of the presence of metalloproteinases and urokinases mainly in neoplastic cells $[19,39,40]$ has opened the possibility of reengineering $B$. anthracis toxin (mutated PA) to be activated by uPA and MMP proteases. In the early 2000s, Liu and colleagues synthesized PA variants PA-L1-I210A and PA-U2-R200A, modifying the site of furin action to be cleaved specifically by MMP, and uPA, respectively, on the cell membrane $[14,18,27,41]$. This modified Bacillus anthracis toxin was selective to cells that express both proteases in their cell membrane and had diminished off-target cytotoxicity when 
compared to native Bacillus anthracis toxin [18] Since then, cytotoxicity tests and xenotransplantation studies, using mouse models, have been performed on human cell lines of head and neck carcinomas, melanomas and lung, uterine, and intestinal carcinomas [18,39,40,42], as well as in murine tumors, such as fibrosarcomas, Lewis carcinomas, and melanomas [19,36].

In this study, animals were selected according to pre-defined criteria, and biopsies of their oral lesions were taken to confirm the diagnosis of melanoma. The dogs received intratumoral injections and tumor progression was assessed for 14 days, followed by surgical resection of the lesions for ethical reasons.

We decided to first inject the re-engineered anthrax toxin intratumorally to assess the clinical response of dogs, before systemically administering the toxin. In an experimental study, Peters and colleagues [43] found 32-87\% tumor reduction in B16 melanomas transplanted into BL6 mice after treatment with an engineered anthrax toxin, but complete tumor remission was not achieved. Based on the cRECIST v 1.0 [29] all five dogs in our study showed stable disease when tumor diameters were considered. Four dogs had 12 to $63 \%$ reduction in OMM volume. According to literature data, OMM, in general, have very poor prognosis, with the possibility to metastasize to the lungs and lymph nodes. The overall median survival time is less than 36 months, depending on the size, histopathology of the tumor, and the stage of the disease [2]. Therefore, it is difficult to predict what would happen with the present OMM cases without treatment.

This study did not aim to evaluate the effect of the treatment on the survival. However, it has been possible to detect that, even with a short period of intratumoral treatment with the anthrax toxin, some clinical benefits were observed. The diseases became stable according to cRECIST and there was decreased bleeding.

Systemic parenteral administration of Bacillus anthracis toxin has been used in several mouse studies and provides adequate diffusion of toxin throughout the tumor tissue, mainly reaching CMG2 receptors in endothelial cells of the capillaries, venules, and arterioles [36]. Necrosis of blood-vessel endothelial cells was also observed in our canine melanoma samples after intratumoral toxin injection. However, intratumoral administration provides irregular distribution by passive or facilitated diffusion of proteins and the toxin may not reach tumor endothelial cells, which is the main site of action of anthrax toxin. Inhibition of the MAPK pathway by LF in endothelial cells does not promote apoptosis immediately, but inhibits the proliferation of these cells within $72 \mathrm{~h}$ [27]. Thus, a lack of a simultaneous, direct cytotoxic effect on neoplastic, stromal, and especially endothelial cells in solid tumors may have contributed to the limited tumor response in our study. In fact, in this study, we could not prove that the toxin indeed binds to the tumor cells, as we only have indirect evidence. OMM cells showed positivity for immunostainings of uPA, UPAR, MMP-2, MT1-MMP, and TIMP-2. After intratumoral treatment with the anthrax toxin, necrotic areas were seen through histopathology, meaning that tumor cells were dead. In the same samples, we could see necrosis of blood vessels endothelial cells. Therefore, we argue that necrosis of OMM cells could be a direct effect of the toxin, and/or the OMM cell necrosis could result from the impairment of blood circulation due to necrosis of blood vessel walls. The dogs' immune system may have also contributed to the results obtained in our study. The Bacillus anthracis toxin can stimulate production of monoclonal antibodies throughout the treatment, which may neutralize the toxin and decrease its antitumor activity. Brossier et al. (2004) [44] reported lower cytotoxicity when monoclonal antibodies were used associated with B. anthracis toxin in cultured macrophages and decreased lethality in mice infected with the anthrax toxin. Liu et al. (2016) [27] used immunosuppressors such as pentostatin and cyclophosphamide associated with the reengineered anthrax toxin treatment in metastatic carcinoma. The authors found that this treatment had prolonged the anti-tumor effects, which lasted 10 days after the first cycle of therapy, by blocking neutralizing antibody production. This result may explain why tumors in dogs 1 and 2 decreased until day 7 in our experiment. 


\section{Conclusions}

In summary, canine OMM in our study expressed uPA, uPAr, and metalloproteinases. The re-engineered anthrax toxin created by Liu, Leppla and Bugge showed antitumor activity and no systemic effects in dogs with OMM when administered intratumorally. Dogs had partial response or stable disease, which are considered acceptable results for OMM that are very aggressive tumors in canines. Future studies should be aimed at investigating the systemic administration of anthrax toxin to treat, not only the primary tumors, but also the melanoma metastasis.

\section{Materials and Methods}

\subsection{Animals}

The study was performed in accordance with protocols approved by the Animal Ethics Committees of the Veterinary Hospital at Anhembi Morumbi University (UAM), School of Medicine of the University of São Paulo (FM-USP), and School of Veterinary Medicine and Animal Science of the University of São Paulo (FMVZ-USP), Brazil. The Animal Study Proposal Numbers and date of approval were, respectively: 00720141 Anhembi Morumbi (approved on June 27, 2014), 052/14 FM-USP (approved on July 17, 2014), 8798100314 FMVZ-USP (approved on May 14, 2014). The protocol was approved by all the Animal Ethics Committees before the the study began.

Five dogs bearing OMM were selected according to predefined criteria (Table 7). All dogs were examined at the Veterinary Hospital at Anhembi Morumbi University and had their OMM diagnosed by cytology or histopathology.

Table 7. Criteria for the inclusion of dogs in the reengineered anthrax toxin clinical study.

\begin{tabular}{cc}
\hline Criteria & Ideal Condition \\
\hline Histopathological or cytological diagnosis & Melanoma \\
Localization of the tumor & Oral cavity (mandible or maxila), and measurable \\
wadiographic exam of the thorax & No metastasis in lungs \\
Ultrasound examination of abdomen & No metastasis in liver and spleen \\
liver and kidney function & Good general condition. \\
\hline
\end{tabular}

Tumor volume was calculated using the formula: volume $=\left(\right.$ length $\times$ width $\left.{ }^{2}\right) / 2$ [26].

\subsection{Reengineered Anthrax Toxin}

PA, PA-U2-R200A, PA-L1-I210A, LF, and FP proteins were constructed and purified as previously described $[13,19,20,28]$ by the Laboratory of Parasitic Diseases of the National Institute of Allergy and Infectious Diseases of the National Institutes of Health (NIH) in Bethesda, MD, USA. The modified toxin was approved by the National Sanitary Surveillance Agency (ANVISA) of the Brazilian Ministry of Health to be acquired by the Laboratory of Experimental Oncology of the Department of Pathology at the FMVZ-USP, and was kept in a freezer at $-80^{\circ} \mathrm{C}$.

\subsection{Clinical Study}

Dogs received three or six intratumoral injections of $375 \mu \mathrm{g}$ PA-U2-R200A + $375 \mu \mathrm{g}$ PA-L1-I210A $+250 \mu \mathrm{g}$ LF in $2 \mathrm{~mL}$ of PBS for one or two weeks, every other day prior to surgery. The longest and shortest tumor diameters were measured with digital calipers with dogs put under general anesthesia on days $0,2,4,7,9,11$, and 14 of study. Physical examination and blood tests (blood cell and platelet counts, packet cell volume, ALT, AST, urea, creatinine) were performed to assess the dogs' condition during treatment with the engineered anthrax toxin. Tumor excision was performed either on day 7 or 14 . 
The clinical response to intratumoral treatment with the reengineered anthrax toxin was evaluated by measuring the longest tumor length and the variation of tumor volume over seven or 14 days, with day 0 the first day of toxin administration and tumor measurements taken under general anesthesia at least on days $0,2,4$, and 7, 9, or 14 in each of the five dogs. Tumor responses were classified according to canine Response Evaluation Criteria in Solid Tumors (cRECIST) v 1.0 [29] and characterized as: Complete response (CR), disappearance of all target lesions; partial response (PR), at least 30\% reduction in tumor volume; stable disease (SD), less than $30 \%$ reduction or up to $20 \%$ increase in tumor volume; and progressive disease (PD), at least a 20\% increase of the initial tumor volume [29].

\subsection{OMM Histopathology and Immunostaining}

OMM samples taken from the five dogs before, and after, treatment were routinely processed for embedding in paraffin wax, and the $4 \mu \mathrm{m}$ sections were stained with hematoxylin and eosin for diagnosis. Additional slices of the paraffin blocks were collected in salinized slides and immunostained with uPA (urokinase plasminogen activator), uPAR (uPA receptor), MMP-2 (metalloproteinase 2), MT1-MMP (membrane MMP), or TIMP-2 (metalloproteinase inhibitor) primary antibodies (Table 8). For immunohistochemistry, $4 \mu \mathrm{m}$ slices were cut from the paraffin blocks, dewaxed in xylene, and hydrated in alcohol, followed by antigen retrieval with citrate buffer at $\mathrm{pH} 6.0$ in a Dako Pascal S2800 pressure cooker (Dako Cytomation, Carpinteria, CA, USA). The slides were then washed in deionized water, the endogenous peroxidase was blocked with $\mathrm{H}_{2} \mathrm{O}_{2}$ solution for $30 \mathrm{~min}$, followed by another washing in deionized water and phosphate buffered saline (PBS) solution. Blocking of non-specific proteins followed. The slices were then incubated with the primary antibodies (Table 8) at $4{ }^{\circ} \mathrm{C}$ for $12-18 \mathrm{~h}$ and washed with PBS buffer prior to the use of the polymer detection system (Histofine ${ }^{\circledR}$ Simple Stain ${ }^{\mathrm{TM}}$ Max PO; Nichirei Biosciences Inc., Tokyo, Japan) and the chromogen (AEC Substrate Chromogen Ready-to-Use, Dako). The slides were counterstained with Harris hematoxylin and mounted in Permount ${ }^{\mathrm{TM}}$ aqueous mounting medium (Munchen, Germany). Additional paraffin slices of the same blocks were treated with the same immunohistochemistry protocols, but without the primary antibodies, and used as negative controls.

Table 8. Antibodies used for the immunohistochemical analysis of canine OMM samples.

\begin{tabular}{cccccc}
\hline Antibody & Code & $\begin{array}{c}\text { Mono/ } \\
\text { Polyclonal }\end{array}$ & $\begin{array}{c}\text { Mouse or } \\
\text { Rabbit }\end{array}$ & Dilution & $\begin{array}{c}\text { Subcellular } \\
\text { Localization }\end{array}$ \\
\hline uPA H140-Santa Cruz & Sc14019 & Polyclonal & rabbit & $1: 200$ & Cytoplasm \\
uPAR-Dako & M7294 & Monoclonal & mouse & $1: 200$ & Membrane \\
MMP-2-Abcam & Ab86607 & Monoclonal & mouse & $1: 200$ & Membrane \\
MT1-MMP-Abcam & Ab53712 & Polyclonal & rabbit & $1: 200$ & Membrane \\
TIMP-2-Abcam & b1828 & Monoclonal & mouse & $1: 200$ & Membrane \\
Ki67-Dako & M7240 & Monoclonal & Mouse & $1: 50$ & Nucleus \\
\hline
\end{tabular}

Antibodies against Ki-67 (Table 8) were applied for immunostainings of OMM samples, collected before and after treatment with reengineered anthrax toxin, and the positive nuclei were counted in order to evaluate cell proliferation.

Author Contributions: Conceptualization, A.T.N., M.L.Z.D., J.M.W., S.H.L., S.L., and T.H.B.; methodology, A.T.N., M.K.N., I.I.M.d.F., M.L.Z.D. and C.O.M.d.S.G.; formal analysis, A.T.N., M.K.N., and I.I.M.d.F.; investigation, A.T.N., M.K.N., I.I.M.d.F., A.C.M. and C.O.M.d.S.G.; resources, S.L. and M.L.Z.D.; data curation, A.T.N., M.K.N., I.I.M.d.F., J.L.G., J.G.X., M.S. and C.O.M.d.S.G.; writing-original draft preparation, A.T.N.; writing-review and editing, M.L.Z.D.; visualization, M.L.Z.D.; supervision, M.L.Z.D.; project administration, M.L.Z.D.; funding acquisition, M.L.Z.D.; data curation, Methodology, N.V.S. All authors have read and agreed to the published version of the manuscript.

Funding: This study was supported by grants from the National Council for Scientific and Technological Development (CNPQ) of the Brazilian Ministry of Science and Technology, Innovation and Communications (Process number 400250/2014-4), the São Paulo Research Foundation, (FAPESP - Process Number 2015/16776-3), and the NIDCR and NIAID Intramural Research Programs. Andreia Caringi Miraldo (Process Number 2015/25158-1), 
Márcia Kazumi Nagamine (Process Number 2016/20479-7) and Ivone Izabel Mackowiak da Fonseca (Process Number 2017/12855-1) were recipients of fellowships from FAPESP.

Acknowledgments: This study is part of the PhD research of Adriana Tomoko Nishiya at the Oncology Graduate Program of the School of Medicine of the University of São Paulo (FM-USP), São Paulo, Brazil. We thank Marguiti Izaura Soares for technical assistance.

Conflicts of Interest: The authors declare no conflicts of interest.

\section{References}

1. Bergman, P.J. Canine Oral Melanoma. Clin. Tech. Small Anim. Pract. 2007, 22, 55-60. [CrossRef]

2. Nishiya, A.T.; Massoco, C.O.; Felizzola, C.R.; Perlmann, E.; Batschinski, K.; Tedardi, M.V.; Garcia, J.S.; Mendonça, P.P.; Teixeira, T.F.; Dagli, M.L.Z. Comparative Aspects of Canine Melanoma. Vet. Sci. 2016, 3, 7. [CrossRef]

3. Williams, L.E.; Packer, R.A. Association between lymph node size and metastasis in dogs with oral malignant melanoma: 100 cases (1987-2001). J. Am. Vet. Med. Assoc. 2003, 222, 1234-1236. [CrossRef] [PubMed]

4. Tuohy, J.L.; Milgram, J.; Worley, D.R.; Dernell, W.S. A review of sentinel lymph node evaluation and the need for its incorporation into veterinary oncology. Vet. Comp. Oncol. 2009, 7, 81-91. [CrossRef] [PubMed]

5. Esplin, D.G. Survival of dogs following surgical excision of histologically well differentiated melanocytic neoplasms of the mucous membranes of the lips and oral cavity. Vet. Pathol. 2008, 45, 889-896. [CrossRef] [PubMed]

6. Harvey, H.J.; MacEwen, E.G.; Braun, D.; Patnaik, A.K.; Withrow, S.J.; Jongeward, S. Prognostic criteria for dogs with oral melanoma. J. Am. Vet. Med. Assoc. 1981, 178, 580-582. [PubMed]

7. Boston, S.E.; Lu, X.; Culp, W.T.; Montinaro, V.; Romanelli, G.; Dudley, R.M.; Liptak, J.M.; Mestrinho, L.A.; Buracco, P. Efficacy of systemic adjuvant therapies administered to dogs after excision of oral malignant melanomas: 151 cases (2001-2012). J. Am. Vet. Med. Assoc. 2014, 245, 401-407. [CrossRef]

8. Bergman, P.J.; Wolchok, J.D. Of mice and men (and dogs): Development of a xenogeneic DNA vaccine for canine oral malignant melanoma. Cancer Ther. 2008, 6, 817-826.

9. Grosenbaugh, D.A.; Leard, A.T.; Bergman, P.J.; Klein, M.K.; Meleo, K.; Susaneck, S.; Hess, P.R.; Jankowski, M.K.; Jones, P.D.; Leibman, N.; et al. Safety and efficacy of a xenogeneic DNA vaccine encoding for human tyrosinase as adjunctive treatment for oral malignant melanoma in dogs following surgical excision of the primary tumor. Am. J. Vet. Res. 2011, 72, 1631-1638. [CrossRef]

10. Hoopes, P.J.; Wagner, R.J.; Duval, K.; Kang, K.; Gladstone, D.J.; Moodie, K.L.; Crary-Burney, M.; Ariaspulido, H.; Veliz, F.A.; Steinmetz, N.F.; et al. Treatment of Canine Oral Melanoma with Nanotechnology-Based Immunotherapy and Radiation. Mol. Pharm. 2018, 15, 3717-3722. [CrossRef]

11. Suzuki, D.O.H.; Berkenbrock, J.A.; Frederico, M.J.S.; Silva, F.R.M.B.; Rangel, M.M.M. Oral Mucosa Model for Electrochemotherapy Treatment of Dog Mouth Cancer: Ex Vivo, In Silico, and In Vivo Experiments. Artif. Organs. 2018, 42, 297-304. [CrossRef] [PubMed]

12. Wouda, R.M.; Hocker, S.E.; Higginbotham, M.L. Safety evaluation of combination carboplatin and toceranib phosphate (Palladia) in tumour-bearing dogs: A phase I dose finding study. Vet. Comp. Oncol. 2018, 16, E52-E60. [CrossRef] [PubMed]

13. Bachran, C.; Leppla, S.H. Tumor Targeting and Drug Delivery by Anthrax Toxin. Toxins 2016, 8, 197. [CrossRef] [PubMed]

14. Liu, S.; Aaronson, H.; Mitola, D.J.; Leppla, S.H.; Bugge, T.H. Potent antitumor activity of a urokinase-activated engineered Bacillus anthracis toxin. Proc. Natl. Acad. Sci. USA 2003, 100, 657-662. [CrossRef]

15. Liu, S.; Bugge, T.H.; Leppla, S.H. Targeting of tumor cells by cell surface urokinase plasminogen activator-dependent Bacillus anthracis toxin. J. Biol. Chem. 2001, 276, 17976-17984. [CrossRef]

16. Liu, S.; Bugge, T.H.; Frankel, A.E.; Leppla, S.H. Dissecting the urokinase activation pathway using urokinase-activated Bacillus anthracis toxin. Methods Mol. Biol. 2009, 539, 175-190.

17. Klimpel, K.R.; Molloy, S.S.; Thomas, G.; Leppla, S.H. Bacillus anthracis toxin protective antigen is activated by a cell-surface protease with the sequence specificity and catalytic properties of furin. Proc. Natl. Acad. Sci. USA 1992, 89, 10277-10281. [CrossRef] 
18. Liu, S.; Redeye, V.; Kuremsky, J.G.; Kuhnen, M.; Molinolo, A.; Bugge, T.H.; Leppla, S.H. Intermolecular complementation achieves high-specificity tumor targeting by Bacillus anthracis toxin. Nat. Biotechnol. 2005, 23, 725-730. [CrossRef]

19. Rønø, B.; Rømer, J.; Liu, S.; Bugge, T.H.; Leppla, S.H.; Kristjansen, P.E. Antitumor efficacy of a urokinase activation-dependent Bacillus anthracis toxin. Mol. Cancer Ther. 2006, 5, 89-96. [CrossRef]

20. Schafer, J.M.; Peters, D.E.; Morley, T.; Liu, S.; Molinolo, A.A.; Leppla, S.H.; Bugge, T.H. Efficient targeting of head and neck squamous cell carcinoma by systemic administration of a dual uPA and MMP-activated engineered Bacillus anthracis toxin. PLoS ONE 2011, 6, e20532. [CrossRef]

21. Andreasen, P.; Egelund, R.; Petersen, H. CMLS, The plasminogen activation system in tumor growth, invasion, and metastasis. Cell. Mol. Life Sci. 2000, 57, 25-40. [CrossRef] [PubMed]

22. Nakaichi, M.; Yunuki, T.; Okuda, M.; Une, S.; Taura, Y. Activity of matrix metalloproteinase-2 (MMP-2) in canine oronasal tumors. Res. Vet. Sci. 2007, 82, 271-279. [CrossRef] [PubMed]

23. Docampo, M.J.; Cabrera, J.; Rabanal, R.M.; Bassols, A. Expression of matrix metalloproteinase-2 and -9 and membrane-type 1 matrix metalloproteinase in melanocytic tumors of dogs and canine melanoma cell lines. Am. J. Vet. Res. 2011, 72, 1087-1096. [CrossRef] [PubMed]

24. Bailey, T.R.; Paulsen, D.B.; Sehgal, I.; Hosgood, G. Immunohistochemical staining of urokinase plasminogen activator-like and urokinase plasminogen activator receptor-like proteins in the urinary tract of healthy dogs. Am. J. Vet. Res. 2006, 67, 1628-1634. [CrossRef] [PubMed]

25. Santos, A.; Lopes, C.; Marques, R.M.; Amorim, I.; Ribeiro, J.; Frias, C.; Vicente, C.; Gärtner, F.; de Matos, A. Immunohistochemical analysis of urokinase plasminogen activator and its prognostic value in canine mammary tumours. Vet. J. 2011, 189, 43-83. [CrossRef] [PubMed]

26. Spangler, W.L.; Kass, P.H. The histologic and epidemiologic bases for prognostic considerations in canine melanocytic neoplasia. Vet. Pathol. 2006, 43, 136-149. [CrossRef] [PubMed]

27. Liu, S.; Liu, J.; Ma, Q.; Cao, L.; Fattah, R.J.; Yu, Z.; Bugge, T.H.; Finkel, T.; Leppla, S.H. Solid tumor therapy by selectively targeting stromal endothelial cells. Proc. Natl. Acad. Sci. USA 2016, 113, E4079-E4087. [CrossRef]

28. Sugiura, K.; Chester, S.C.; Sugiura, M. Studies in a tumor spectrum. II. The growth of a variety of mouse and rat tumors. Cancer 1952, 5, 979-991. [CrossRef]

29. Nguyen, S.M.; Thamm, D.H.; Vail, D.M.; London, C.A. Response evaluation criteria for solid tumours in dogs (v1.0): A Veterinary Cooperative Oncology Group (VCOG) consensus document. Vet. Comp. Oncol. 2015, 13, 176-183. [CrossRef]

30. Paoloni, M.; Khanna, C. Translation of new cancer treatments from pet dogs to humans. Nat. Rev. Cancer 2008, 8, 147-156. [CrossRef]

31. Lindblad-Toh, K.; Wade, C.M.; Mikkelsen, T.S.; Karlsson, E.K.; Jaffe, D.B.; Kamal, M.; Clamp, M.; Chang, J.L.; Kulbokas, E.J.; Zody, M.C.; et al. Genome sequence, comparative analysis and haplotype structure of the domestic dog. Nature 2005, 438, 803-819. [CrossRef] [PubMed]

32. Simpson, R.M.; Bastian, B.C.; Michael, H.T.; Webster, J.D.; Prasad, M.L.; Conway, C.M.; Prieto, V.M.; Gary, J.M.; Goldschmidt, M.H.; Esplin, D.G.; et al. Sporadic naturally occurring melanoma in dogs as a preclinical model for human melanoma. Pigment Cell Melanoma Res. 2014, 27, 37-47. [CrossRef] [PubMed]

33. Gillard, M.; Cadieu, E.; De Brito, C.; Abadie, J.; Vergier, B.; Devauchelle, P.; Degorce, F.; Dréano, S.; Primot, A.; Dorso, L.; et al. Naturally occurring melanomas in dogs as models for non-UV pathways of human melanomas. Pigment Cell Melanoma Res. 2014, 27, 90-102. [CrossRef] [PubMed]

34. Ezzell, J.W.; Ivins, B.E.; Leppla, S.H. Immunoelectrophoretic analysis, toxicity, and kinetics of in vitro production of the protective antigen and lethal factor components of Bacillus anthracis toxin. Infect. Immun. 1984, 45, 761-767. [CrossRef] [PubMed]

35. Wein, A.N.; Peters, D.E.; Valivullah, Z.; Hoover, B.J.; Tatineni, A.; Ma, Q.; Fattah, R.; Bugge, T.H.; Leppla, S.H.; Liu, S. An anthrax toxin variant with an improved activity in tumor targeting. Sci Rep. 2015, 5, 1-8. [CrossRef]

36. Liu, S.; Wang, H.; Currie, B.M.; Molinolo, A.; Leung, H.J.; Moayeri, M.; Basile, J.R.; Alfano, R.W.; Gutkind, J.S.; Frankel, A.E.; et al. Matrix metalloproteinase-activated anthrax lethal toxin demonstrates high potency in targeting tumor vasculature. J. Biol. Chem. 2008, 283, 529-540. [CrossRef]

37. Duesbery, N.S.; Webb, C.P.; Leppla, S.H.; Gordon, V.M.; Klimpel, K.R.; Copeland, T.D.; Ahn, N.G.; Oskarsson, M.K.; Fukasawa, K.; Paull, K.D.; et al. Proteolytic inactivation of MAP-kinase-kinase by anthrax lethal factor. Science 1998, 280, 734-737. [CrossRef] 
38. Moayeri, M.; Leppla, S.H.; Vrentas, C.; Pomerantsev, A.P.; Liu, S. Anthrax Pathogenesis. Annu. Rev. Microbiol. 2015, 69, 185-208. [CrossRef]

39. Abi-Habib, R.J.; Singh, R.; Leppla, S.H.; Greene, J.J.; Ding, Y.; Berghuis, B.; Duesbery, N.S.; Frankel, A.E. Systemic Anthrax Lethal Toxin Therapy Produces Regressions of Subcutaneous Human Melanoma Tumors in Athymic Nude Mice. Clin. Cancer Res. 2006, 12, 7437-7443. [CrossRef]

40. Su, Y.; Ortiz, J.; Liu, S.; Bugge, T.H.; Singh, R.; Leppla, S.H.; Frankel, A.E. Systematic urokinase-activated anthrax toxin therapy produces regressions of subcutaneous human non-small cell lung tumor in athymic nude mice. Cancer Res. 2007, 67, 3329-3336. [CrossRef]

41. Liu, S.; Netzel-Arnett, S.; Birkedal-Hansen, H.; Leppla, S.H. Tumor cell-selective cytotoxicity of matrix metalloproteinase-activated anthrax toxin. Cancer Res. 2000, 60, 6061-6067. [PubMed]

42. Abi-Habib, R.J.; Singh, R.; Liu, S.; Bugge, T.H.; Leppla, S.H.; Frankel, A.E. A urokinase-activated recombinant anthrax toxin is selectively cytotoxic to many human tumor cell types. Mol. Cancer Ther. 2006, 5, 2556-2562. [CrossRef] [PubMed]

43. Peters, D.E.; Hoover, B.; Cloud, L.G.; Liu, S.; Molinolo, A.A.; Leppla, S.H.; Bugge, T.H. Comparative toxicity and efficacy of engineered Bacillus anthracis lethal toxin variants with broad anti-tumor activities. Toxicol. Appl. Pharmacol. 2014, 279, 220-229. [CrossRef] [PubMed]

44. Brossier, F.; Le, M.; Landier, A.; Lafaye, P. Functional Analysis of Bacillus anthracis Protective Antigen by Using Neutralizing Monoclonal Antibodies. Society 2004, 72, 6313-6317. [CrossRef]

(C) 2020 by the authors. Licensee MDPI, Basel, Switzerland. This article is an open access article distributed under the terms and conditions of the Creative Commons Attribution (CC BY) license (http://creativecommons.org/licenses/by/4.0/). 